\title{
Management Quality and Innovation in Emerging Countries
}

\author{
OLEG SIDORKIN* \\ Leibniz-Institute for East and Southeast European Studies and CERGE-EI
}

\begin{abstract}
I study the relationship between management quality and the innovation input and output of firms in ten emerging countries using data from the Management, Organization and Innovation (MOI) Survey. I find that management quality is tightly associated with the decisions of firms to invest in R\&D. An improvement in management quality from the 25 th percentile to the median is associated with a 3.2 percentage point increase in the propensity to invest in $R \& D$. Furthermore, there is a positive but weak association between management quality and product innovation. The empirical results for individual management practices show substantial heterogeneity. The findings hold after controlling for differences in management quality by industries. Additional analysis of management quality asymmetry shows that the results are driven mainly by firms with low quality management.
\end{abstract}

Keywords: management quality, $\mathrm{R} \& \mathrm{D}$, product innovation, emerging countries JEL classification: L2, M2, O3

\section{Introduction}

Recent empirical studies have revealed a positive connection between management quality and innovation in a number of developed countries (Kremp and Mairesse, 2004; Bloom et al., 2017). However, questions remain as to what types of individual management practices are important for innovation input and which types impact innovation output. It is also not clear whether the effects of management quality hold for emerging countries. This paper helps to

\footnotetext{
* Email: sidorkin@ios-regensburg.de. Earlier versions of this paper were published as a CERGE-EI Working Paper \#555 and Innovation Management, Entrepreneurship and Sustainability 2018 conference proceedings. Financial support from the Czech Science Foundation (GA ČR) project P402/10/2310 on 'Innovation, productivity and policy: What can we learn from micro data?' is gratefully acknowledged. The research contributes to the agenda Strategie AV21. I want to thank Martin Srholec, Jan Hanousek, Sasha Prokosheva, Helena Schweiger, Patrick Gaulé, Francesco Lissoni, Krešimir Žigić and participants in the Innovation Management, Entrepreneurship and Sustainability 2018 conference for valuable comments. All errors remaining in this text are the responsibility of the author. I have received many useful comments from participants at the 4th International Conference on Applied Theory, Macro and Empirical Finance (AMEF 2018). I am especially grateful to anonymous referees and Ben Etheridge (University of Essex, Department of Economics) for constructive comments and suggestions. I remain solely responsible for any errors and interpretations.

(C) 2018 Oleg Sidorkin. Licensed under the Creative Commons Attribution - Noncommercial 3.0 Licence (http://creativecommons.org/licenses/by-nc/3.0/. Available at http: //rofea.org.
} 
address these issues by studying how differences in overall management quality and the quality of management practices affect the decisions of firms to invest in innovation input, i.e. to start searching for new solutions ( $R \& D$ propensity), to accelerate their efforts ( $R \& D$ intensity) and, ultimately, to generate innovation output, i.e. introduce new products. As the business environment and overall investment climate in emerging countries are likely to influence innovation decisions, I evaluate whether the discovered effects differ for countries associated with the European Union (members and candidate countries) and non-EU countries.

The literature suggests two main mechanisms that connect management quality and innovation input on one hand, and management quality and innovation output, on the other. First, there is a direct influence of management on innovation output through the individual components of organizational and management processes (Cirera and Maloney, 2017; Teece and Pisano, 1994; Van der Panne, van Beers, and Kleinknecht, 2003). These processes support development of new technologies, new ideas, learning, problem solving, achieving results, aligning corporate goals, searching for outside solutions, and others. I can proxy these individual components with relevant management practices that provide incentives, monitor performance, support long-term goals through targeting, and help to improve production with operation management.

Second, there is an indirect connection between management and innovation input, such as R\&D propensity and efforts. In other words, firms that are able to produce and commercialize (sell, advertise, etc.) products with the help of better management practices, are more likely to start and boost innovation in the first place (Hellmann and Thiele, 2011; Bender et al., 2018).

The results suggest that management quality and innovation decisions are interconnected. The quality of incentives and monitoring practices are highly correlated with starting R\&D investments, and better goal setting (the quality of targeting) is associated with higher innovation efforts. However, only the quality of monitoring practices is associated with better product innovations. I find a stronger association between R\&D investment decisions and management quality for firms in EU countries, but no differences in the correlation between these two indicators on later innovation stages.

My analysis is mainly exploratory and based on correlations, as it is not possible to control for possible endogeneity and estimate causal effects with the data at hand. Nevertheless, a causal relationship between management quality and innovation indicators is likely to hold. The link between management practices and innovation is supported by a number of other studies, e.g. for firms in the United States (Bloom at al., 2017) or on a wider cross-country dataset (Cirera \& Maloney, 2017). 
SIDORKIN Management Quality and Innovation in Emerging Countries

The structure of this paper is as follows. Section 2 reviews the literature. Section 3 describes the dataset, key management measures, and data patterns. Section 4 outlines the empirical model. Section 5 presents empirical results and prospects for future research. Section 6 provides concluding remarks.

\section{Literature Review}

Management, and more recently economics, literature has established a close connection between management and firms' innovation. Scholars consider management quality an essential capability that allows firms to achieve innovation success.

Teece (1986) is among the first who highlights the importance of capabilities and complementary assets as pre-requisites for successful product innovation and subsequent new product commercialization. In particular, the author suggests that the availability of capabilities, such as the appropriability regime, the dominant design and complementary assets, are crucial for promoting innovation efforts. The author also points out the direct role of these capabilities in the production of new products and the capturing of profits from innovation. Further, capabilities are not static. For example, Hayes, Wheelwright, and Clark (1988) highlight the importance of continuous capability development (accumulation). They argue that a better understanding of production and management processes is associated with innovation success. According to Hayes, Wheelwright, and Clark (1988), the strategic development of capabilities is a deliberate process. If firms aim to improve innovation process, they need to re-structure their organizational and managerial processes to promote new technologies (Teece and Pisano, 1994).

The quality of management and individual management practices is considered one of the key capabilities for innovation (Cirera and Maloney, 2017). In their in-depth review of management practices, Adams, Bessant, and Phelps (2006) point out that inputs' management, knowledge management, strategic management, organizational culture, and other practices are essential for innovative firms. Hamel (2006) and his colleagues identified 175 innovative management practices in the 20th century, such as scientific management (time and motion studies), cost accounting and variance analysis, and many others. Firms that can manage knowledge inflows and search for outside innovations, e.g. in academic research (Jaffe, 1989; Drivas et al., 2017), are able to create subsequent in-house innovations on the technological frontier. Furthermore, knowledge management is also beneficial for innovation via imitation, which is a prevalent form of innovation in many emerging economies (Kim, 1997). As management is a multi-dimensional phenomenon, in the next step I limit the analysis to four core practices: operations, incentives, targeting, and monitoring.

Using a dynamic capabilities framework, Teece and Pisano (1994) consider several dimensions of management quality that are important for my analysis. The authors point out 
that learning helps firms to achieve production goals ${ }^{1}$,i.e. learning facilitates problem solving in operations (manufacturing of existing and new products), as well as technology development (process innovations). Thus, the continuous improvement of operation practices could serve as a catalyst for future innovations.

Teece and Pisano (1994) also argue that firms should provide proper incentives, connecting individual or team behavior to innovation and rewarding high performance. If employees are able to appropriate returns from their innovation activities, this encourages innovation in the first place (Hellmann and Thiele, 2011). Recent experimental evidence (Atkin at al., 2017) suggests that the alignment of incentives within firms is an important factor in the adoption of a new technology. The authors conducted an experiment which involved the diffusion of a new technology for soccer ball manufacturing in Pakistan. They observed substantial resistance to the adoption of more efficient technology. As the payment system (piece-rate payment) might have led to a reduction in the employees' effective wage in the short term, the employees opposed the new technology. As the main focus of this paper is on emerging countries, I expect to observe a strong association between the quality of incentive practices and innovation success.

Once the performance reward system is set, I also expect to observe a link between monitoring practices that track individual and team performance, and innovation. Griffin and Hauser (1996) point out that innovation processes (R\&D efforts) are optimal when focused on long-term goals and that different functional departments work well if they have similar objectives. As a result, target practices supporting long-term goals could be beneficial for the success of more complex innovations.

Empirical research on individual innovation management practices is a challenging task and scholars often focus on their presence (adoption) and measurable outcomes. Studying the quality and connections between different practices is important, but difficult because of their complex qualitative nature. Scholars analyze organizational and managerial qualities that influence new product development both from a theoretical perspective (see Montoya-Weiss and Calantone, 1994; and Van der Panne, van Beers, and Kleinknecht, 2003 for relevant reviews) and as case studies (see Helper and Henderson, 2014 for a discussion of management practices in General Motors). These qualities usually include management characteristics, such as management style, workforce management, performance management and others. Furthermore, measuring these qualities is often not trivial.

The improvement of individual management practices is itself a continuous development which influences firms' innovation performance (Birkinshaw, Hamel, and Mol, 2008). New

\footnotetext{
${ }^{1}$ Continuous improvement, as well as Just-in-Time and Total Quality Control systems are examples of learning practices that have helped Japanese carmakers to achieve advantages in product development over their American and European competitors (Clark and Fujimoto, 1989).
} 


\section{SIDORKIN Management Quality and Innovation in Emerging Countries}

management practices can be developed in-house or adopted from a large pool of existing practices (Birkinshaw and Mol, 2009; Walker, Damanpour, and Devece, 2011). Firms can also improve the quality of existing management practices to achieve higher performance results (Schweiger and Friebel, 2013). As the quality of existing management practices is highly endogenous, establishing a causal relationship between management quality and innovation is difficult.

There is a set of management practices that have been shown to be beneficial for a firm's performance. Kim, Kumar, and Kumar (2012) show that quality management has both direct and indirect positive effects on different types of innovations. Bloom et al. (2017) and Bloom et al. (2014) find a positive connection between management quality, based on individual practices, innovation input (R\&D) and output (patenting) using two different large-scale management surveys. Makri, Lane, and Gomez-Mejia (2006) find that CEO incentives are tightly linked to desirable innovation outputs (both in quantitative and qualitative terms) for firms that are actively innovating. Moreover, they find that incentives that explicitly rely on the desired innovation outcomes help firms to achieve better market performance. Lerner and Wulf (2007) also confirm a positive relationship between long-term compensation plans for $R \& D$ managers and innovation output.

There is considerable heterogeneity in the adoption and effects of management practices, which may vary by firm, industry and country characteristics. For example, innovative industries focus more on people management, motivation and incentives, while capitalintensive industries pay attention to monitoring and targeting (Bloom et al., 2014). Broszeit et al. (2016) show that small and medium sized firms have lower management quality than large firms. Better managed firms tend to employ workers with higher human capital, including managerial ability (Bender et al., 2018). Moreover, Bloom, Schweiger, and Van Reenen (2012) find that the positive effects of management quality on firms' performance hold for emerging countries.

Although there is a theoretical association between innovation and individual management practices, in reality management quality may play a different role in decisions to begin research activities, further invest in development, and produce a novel product. Therefore, I study which management practice is important for the innovation process. In particular, I focus on the association between the quality of management practices and R\&D propensity, R\&D intensity and, finally, new product development. I focus specifically on emerging countries, which have received less attention in the current literature. I explicitly control for other conditions traditionally considered in the empirical literature on this topic, such as a wide range of technological capabilities (Trott, 2012). 


\section{Data Description}

An empirical study of the relationship between management and innovation is a challenging task because large cross-country surveys covering both topics in detail are relatively scarce. Recently, there have been a number of attempts to improve data collection on innovation (Mairesse and Mohnen, 2010). Community Innovation Surveys (CIS) have helped researchers to study the innovation activity of EU firms and firms from some non-member nations (Canada, USA, and others). Although CISs do not include questions related to management quality, they cover a number of questions about the introduction of new business practices (organizational innovation). There are a number of empirical studies based on CIS data (see, e.g. Birkinshaw and Mol, 2009, who analyzed drivers of management changes based on the UK Innovation Survey). For the period 2013 - 2015, the World Bank conducted a crosscountry Enterprise Survey, which included questions on innovation and management practices (Cirera and Maloney, 2017). There are also several recent country-level surveys, e.g. the US Management and Organizational Practices Survey (MOPS) conducted in 2010 and the German Management and Organizational Practices (GMOP) Survey conducted in 20142015. In this study, I focus on the first cross-country survey that contains data on management quality and innovation (input and output) in the context of emerging countries.

During the period of October 2008-November 2009, the European Bank for Reconstruction and Development (EBRD) and the World Bank conducted a Management, Organization and Innovation (MOI) Survey ${ }^{2}$, based on recommendations from works by Bloom and Van Reenen (2006). Details on sampling methodology are presented in Appendix C. The managers of about 1,400 firms from 10 emerging countries in Eastern Europe and the Commonwealth of Independent States (CIS), i.e. Belarus, Bulgaria, Kazakhstan, Lithuania, Poland, Romania, Russia, Serbia, Ukraine, and Uzbekistan, were interviewed face-to-face. The organizers conducted the survey in the Russian Far East between February and April 2010. The questionnaire was tested in two pilot surveys in the USA and Ukraine, and in the UK before implementation in the MOI survey. The survey focused mainly on production and operation activities, which include four groups of management practices: operations, monitoring, targeting, and incentives. MOI is one of first datasets that allowed researchers to study the relationships between management quality and innovation in emerging countries.

The data consists of information from manufacturing firms with between 10 and 5,500 employees. All monetary values have been converted to constant 2005 international US dollars. Original MOI data do not include financial information. However, the EBRD provided me with an additional dataset, in which completed MOI survey interviews are

\footnotetext{
2 The EBRD-World Bank Management, Organization and Innovation (MOI) Survey dataset is available at http://www.ebrd.com/what-we-do/economic-research-and-data/data/moi.html
} 


\section{SIDORKIN Management Quality and Innovation in Emerging Countries}

matched to balance sheets and profit and loss statements from Bureau Van Dijk's Orbis database (see Appendix D for details on merging). Based on the merged data, I use the measure of physical capital (fixed assets per employee) and the firm's efficiency (return on total assets, ROTA), which are the factors influencing a firm's performance. As a result, they could be an important factor affecting innovation decisions (Crépon, Duguet, and Mairesse, 1998; Mohnen and Hall, 2014). Unfortunately, financial data are missing for some firms in the Orbis dataset, which leads to a sample reduction in the merged dataset by about $41 \%$ (from 697 to 410 observations). As a result, I use financial variables for robustness checks and focus mainly on the full merged dataset.

The main variables used in the analysis are converted to logarithms where applicable. The summary statistics are presented in Table 1. I examine innovation input and output in terms of:

- Decisions of firms to engage in R\&D (i.e. whether a firm has invested in R\&D). In my sample, about $26 \%$ of firms invested in R\&D in the last complete fiscal year of the study.

- Decisions of firms to accelerate research efforts - R\&D intensity ( $R \& D$ spending per employee). Among the firms that engaged in $R \& D$, the average amount invested was about USD 104 of constant USD 2005 per employee) in the last complete fiscal year of the study.

- Innovation output as new products introduced over the last three years of the study (a binary variable). In my sample, about $66.4 \%$ of firms introduced new products over the last 3 years. This share is higher for firms that invested in R\&D research $(91.0 \%)$, than those which did not $(57.9 \%)$. The difference in the means of these groups is significantly different from zero according to the two-sample $t$-test with equal variances $(t=-11.3,830$ d.o.f.).

An average firm in my sample has about 198 permanent full-time and part-time employees. Firm size is an essential parameter to control, as firms may benefit from economies of scale (Earl and Gault, 2004; Huergo and Jaumandreu, 2004). The average share of employees with higher education is about $27.0 \%$, which is a measure of human capital quality. Employees serve as an internal source of knowledge, which has a positive impact on innovation outcomes (Dakhli and De Clercq, 2004; Elche-Hotelano, 2011). Further, I control for the firm's age (the average firm age in the dataset is about 31 years), as newer firms tend to be more innovative (Huergo and Jaumandreu, 2004). The share of young firms (less than 10 years) in the dataset is $19.2 \%$. Further, I control for the firm's legal status, as successful innovation may benefit from stable shareholding arrangements, which can provide incentives for top management and effectively delegate monitoring (Soskice, 1997). About 25\% of the firms in my sample are shareholding companies with shares traded on the national or international stock markets. 
Review of Economic Analysis 11 (2019) 83-116

Table 1: Descriptive statistics of variables included in the analysis

\begin{tabular}{|l||c|c|c|c|c|}
\hline \multicolumn{1}{|c||}{ Variables } & Obs. & Min & Max & Mean & St.Dev. \\
\hline \hline \multicolumn{7}{|c|}{ Dependent variables } \\
\hline R\&D propensity & 697 & 0 & 1 & 0.257 & 0.437 \\
\hline Ln(R\&D spending + 1) & 697 & 0 & 1.795 & 0.065 & 0.214 \\
\hline New products introduced & 697 & 0 & 1 & 0.664 & 0.473 \\
\hline \multicolumn{7}{|c||}{ Control variables } \\
\hline Management z-score (aggregate) & 697 & -4.008 & 1.802 & -0.062 & 1.050 \\
\hline Operations z-score & 697 & -4.497 & 0.814 & -0.016 & 0.994 \\
\hline Monitoring Z-score & 697 & -2.433 & 1.138 & -0.042 & 0.679 \\
\hline Targeting z-score & 697 & -1.972 & 1.332 & -0.047 & 1.009 \\
\hline Incentives z-score & 697 & -2.448 & 0.723 & -0.047 & 0.688 \\
\hline Ln(employees) & 697 & 3.401 & 7.926 & 4.882 & 0.817 \\
\hline Higher education (share) & 697 & 0 & 1 & 0.270 & 0.219 \\
\hline Ln(firm's age) & 697 & 0 & 5.338 & 3.030 & 0.944 \\
\hline Shareholding company (traded) & 697 & 0 & 1 & 0.254 & 0.436 \\
\hline $\begin{array}{l}\text { Ln(permanent full-time employee } \\
\text { weekly hours) }\end{array}$ & 697 & 3.296 & 4.094 & 3.718 & 0.086 \\
\hline Capital city & 697 & 0 & 1 & 0.283 & 0.451 \\
\hline Foreign (largest owner) & 697 & 0 & 1 & 0.082 & 0.274 \\
\hline High-speed Internet connection & 697 & 0 & 1 & 0.806 & 0.395 \\
\hline Imports pressure & 697 & 0 & 1 & 0.663 & 0.473 \\
\hline Ln(fixed assets) & 410 & -9.390 & 5.522 & 1.466 & 1.790 \\
\hline Return on total assets (ROTA) & 410 & -71.800 & 75.910 & 3.651 & 16.218 \\
\hline
\end{tabular}

About $8 \%$ of firms have foreign firms or individuals as their largest owners. Foreign-owned firms can often have lower innovation costs and higher R\&D efforts due to better access to new technologies, lower costs of financing, and better organizational practices (Guadalupe, Kuzmina, and Thomas, 2012). In addition, I control whether firms have a high-speed internet connection at their premises as one of the measures of technological capability (Kim, 1997). Other variables include weekly working hours of permanent full-time employees to control for the effectiveness of human resource management (Laursen and Foss, 2003). I also take into account firms' locations (whether a firm is located in a capital city) as geographical concentration is linked to knowledge externalities and the availability of skilled labor, and therefore to innovation propensity (Audretsch and Feldman, 1996). As the market environment can be an important innovation driver, I account for market competition with imports from abroad.

Similar to Bloom, Schweiger, and Van Reenen (2012), I group questions into four main categories: operations (one question), monitoring (seven questions), targets (one question), 
SIDORKIN Management Quality and Innovation in Emerging Countries

and incentives (three questions). The operations question aims to answer how firms deal with process problems. Monitoring questions reveal the use of production performance indicators. The target questions cover the setting of time targets. Incentives questions are related to employee reward, promotion, and dealing with poor performance.

The survey mainly includes closed questions. With regard to monitoring, I drop one question, as it has a substantial share of missing values. The questions included in the analysis are presented in Appendix B. Although, in general, the definition of "good" and "bad" practice can be subjective and may differ by country, Nicholas Bloom and John Van Reenen, the organizers of the MOI survey, focus on practices that have a straightforward meaning, so that the quality of each practice can be revealed based on responses to the survey ${ }^{3}$.

Following the suggestions of Bloom, Schweiger, and Van Reenen (2012) for the MOI survey, I assign scores to responses for each management question such that a higher score means a higher quality of the management practice analyzed. Although this assignment may appear somewhat subjective, survey organizers have attempted to formulate the questions so that the answers could be ranked. Accordingly, I follow their recommendations. Further, I calculate zscores by normalizing scores for each question to mean zero and standard deviation one ${ }^{4}$. Normalization is a necessary step because each question could have a different number of answers and thus I would need to normalize answers to make them comparable:

$$
z_{m_{i}}=\frac{m_{i}-\bar{m}_{i}}{\sigma_{m_{i}}}
$$

where $z_{m i}$ is the $z$-score of a question $\mathrm{mi}$ in firm $\mathrm{i}, \bar{m}_{i}$ is an unweighted average of a respective question across all countries; $\sigma \mathrm{mi}$ is a standard deviation of a question across all countries.

Second, the z-scores are combined into management practices as a non-weighted average, thus I want to aggregate relevant questions into four distinctive groups:

$$
\bar{m}_{i, P}=\frac{1}{n_{m_{i, P}}} \sum_{m \in P} Z_{m_{i}}
$$

\footnotetext{
3 For example, for Incentives question R.7 "How do you reward this establishment's production target achievement?", the management score and the quality of practice increases from "There are no rewards" (score $=1$ ), to "Only top and middle management is rewarded" (score =2) and finally "All staff is rewarded" (score $=0$ ). Other questions follow a similar logic; nevertheless, one might possibly think of other score combinations for quality increase. See Appendix B for more details.

4 This is a standard way to calculate the aggregate measures of management quality, widely used in other surveys, such as the Management and Organizational Practices Survey (MOPS) and the World Management Survey (WMS).
} 
where $\overline{\mathrm{m}}_{\mathrm{i}, \mathrm{P}}$ is the unweighted average of questions belonging to one of the four management practices $\mathrm{P}$ (operations, monitoring, targets, or incentives) in firm $\mathrm{i} ; \mathrm{n}_{\mathrm{mi}, \mathrm{P}}$ denotes the number of observations.

Further, I construct an aggregate measure of management quality as a non-weighted average of all four practices, since my aim is to have one measure of management quality instead of four.

In this case, all management practices have an equal contribution to this final measure:

$$
\widetilde{M_{l}}=\frac{1}{4}\left(\bar{m}_{i, \text { operations }}+\bar{m}_{i, \text { monitoring }}+\bar{m}_{i, \text { targets }}+\bar{m}_{i, \text { incentives }}\right)
$$

Finally, I calculate the z-scores for $\widetilde{M}_{i}$ to compare management practices across firms. If the value of the $z$-score is positive, it indicates management practice above average ("good" practice); the opposite is true for negative values ("bad" practice):

$$
z_{\widetilde{M}_{i}}=M_{i}=\frac{\widetilde{M}_{i}-\overline{\bar{M}}_{i}}{\sigma_{\widetilde{M}_{i}}}
$$

Table 1 shows the essential summary statistics for dependent variables; main variables of interest, i.e. management z-scores (aggregate and by different practices); and control variables included in the analysis. The distribution of observation by countries included in the analysis is presented in Table 2. Additional frequency tables for time periods and two-digit industry codes are presented in the Appendix Tables A.1-A.2.

The comparison of the aggregate management z-scores across the surveyed countries is presented in Figure 1. As expected, most countries, associated with the European Union (EU) take higher values of the aggregate management z-scores than non-EU countries. Surprisingly, Ukraine shows above average management quality and Lithuania is below average. Uzbekistan and Kazakhstan have the worst management score of all surveyed countries. In EU countries, the mean $z$-score is 0.181 (median $=0.271$ ), while for non-EU countries the average $z$-score is -0.137 (median $=-0.035$ ). According to the two-sample t-test with unequal variances, the difference in means is statistically different from zero at a $1 \%$ level $(t=6.06)$. Therefore, in EU countries variations in management quality might have different effects than in non-EU countries. I study these differences in this paper. The descriptive statistics of z-scores (aggregate and by individual management practices) are presented in Table 1.

The diffusion of four management practices by firm size (small, medium, large, extralarge business) is depicted in Figure 2. In general, management practices are positively associated with firm size. For very small firms, formal management practices are of lesser 
SIDORKIN Management Quality and Innovation in Emerging Countries

Table 2. Summary statistics: Countries

\begin{tabular}{|l||c|c|}
\hline Variables & Obs. & Frequency \\
\hline \multicolumn{2}{|c|}{ Non-EU countries } \\
\hline Belarus & 30 & 4.304 \\
\hline Kazakhstan & 83 & 11.478 \\
\hline Russia & 195 & 27.977 \\
\hline Ukraine & 80 & 11.478 \\
\hline Uzbekistan & 84 & 11.908 \\
\hline Non-EU countries total & 472 & 67.719 \\
\hline \multicolumn{2}{|||}{ EU countries } \\
\hline Bulgaria & 43 & 6.169 \\
\hline Lithuania & 38 & 5.452 \\
\hline Poland & 26 & 3.730 \\
\hline Romania & 50 & 7.174 \\
\hline Serbia & 68 & 9.756 \\
\hline EU countries total & 225 & 32.281 \\
\hline Total & 697 & 100.00 \\
\hline
\end{tabular}

Figure 1: Management z-scores across countries

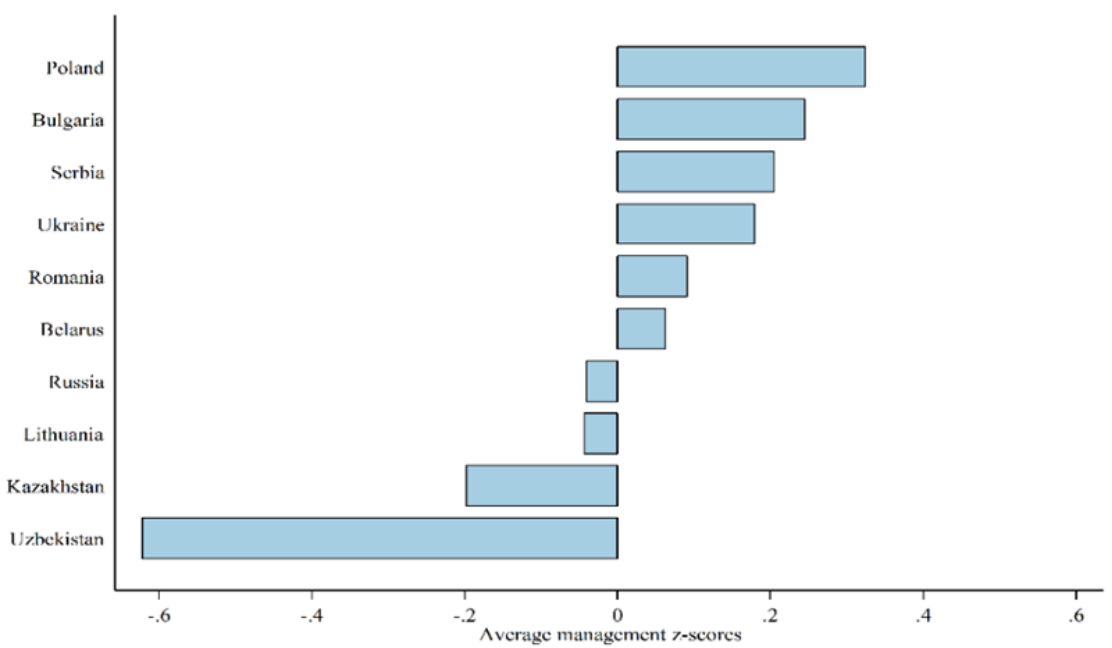

Source: Author's calculations based on the EBRD and the World Bank MOI survey 
Review of Economic Analysis 11 (2019) 83-116

Figure 2: The diffusion of management practices by firm size

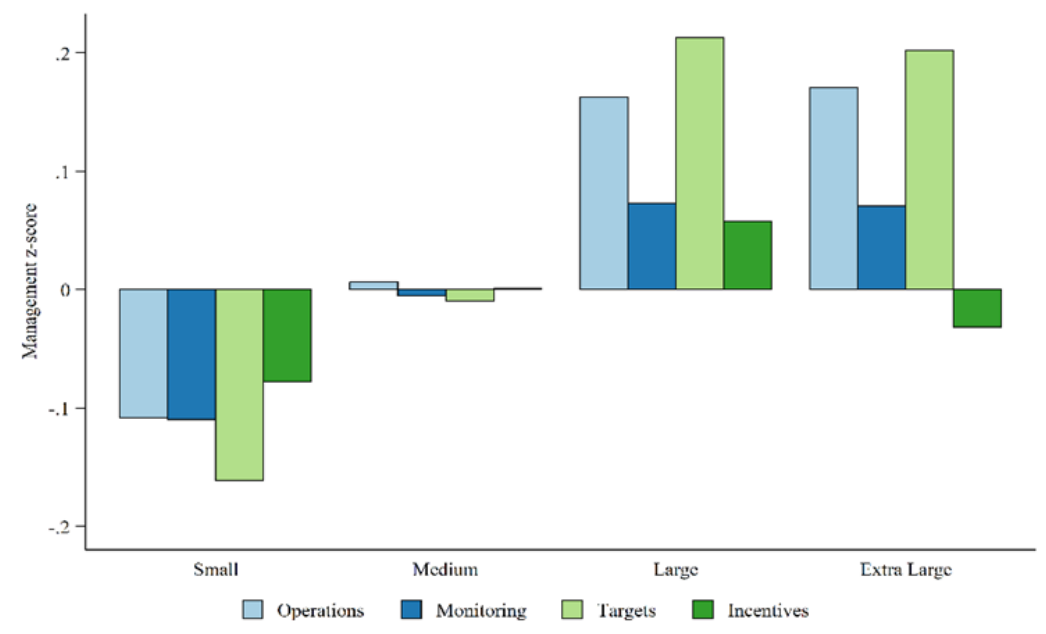

Source: Author's calculations based on the EBRD and the World Bank MOI survey

Figure 3. The diffusion of management practices by R\&D propensity and the introduction of new products
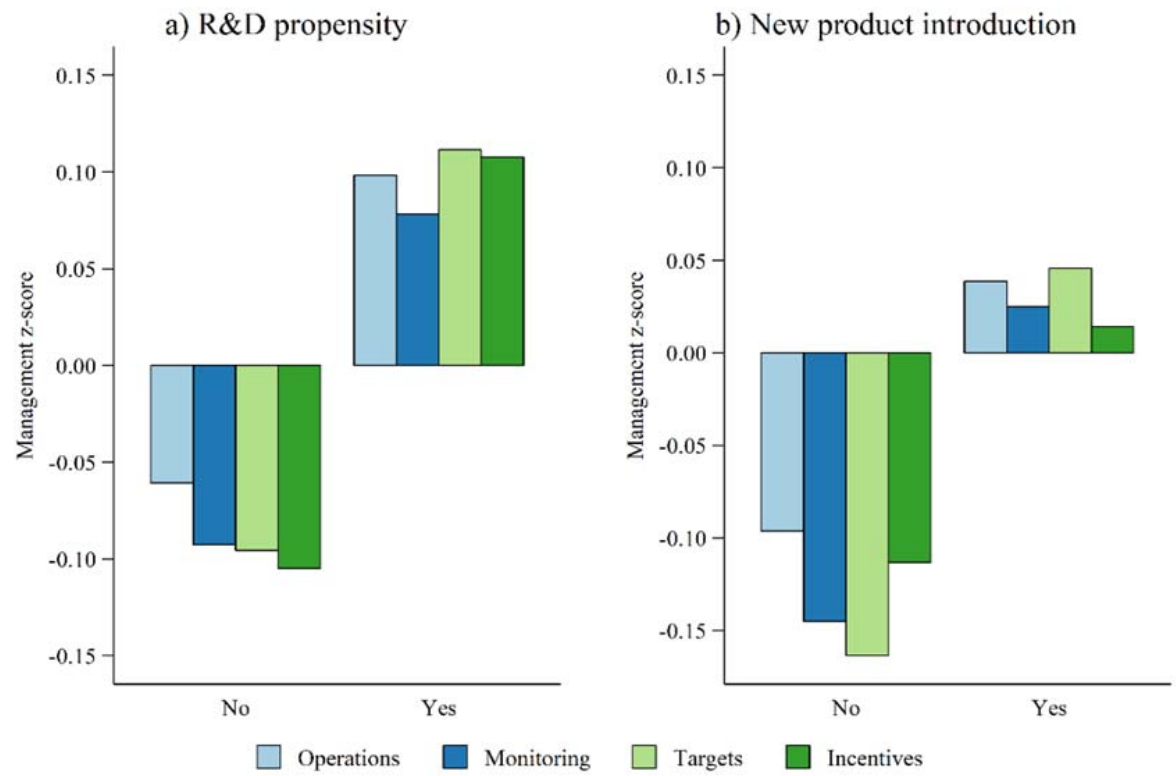

Source: Author's calculations based on the EBRD and the World Bank MOI survey 
SIDORKIN Management Quality and Innovation in Emerging Countries

importance. As the size increases, it becomes more difficult for managers to have direct influence on day-to-day production processes, communication with external sources, innovation activities, and other tasks. Therefore, managers rely on formal practices to manage growing firms.

The diffusion of management scores by R\&D propensity and introduction of new products is presented in Figure 3 above. Innovating firms tend to have higher management scores. The data contains explicit patterns between management quality and innovation, which I study in detail using an empirical model, described in the following section 4.

\section{Methodology}

The empirical model, i.e. the innovation production function, to be estimated is as follows:

$$
\begin{aligned}
& R \& D_{i c}=\alpha_{1} l_{i c}+\beta_{1} k_{i c}+\gamma_{1} M_{i}+\delta_{1} Z_{i c}+u_{1 i c} \\
& y_{i c}=\alpha_{2} l_{i c}+\beta_{2} k_{i c}+\gamma_{2} M_{i}+\delta_{2} Z_{i c}+\theta_{2} R \& D_{i c}+u_{2 i c}
\end{aligned}
$$

where $R \& D_{i c}$ is a measure of innovation input ( $R \& D$ spending per employee) and $y_{i c}$ output (development of new products) of firm $i$ in country $c, l_{i c}$ the logarithm of labor, $k_{i c}$ the logarithm of capital; $M_{i}$ the measure of management quality (aggregate quality of management and four different management practices); $Z_{i c}$ - other control variables which affect innovation, such as workforce characteristics (share of employees with university degrees and the average weekly hours worked), firm characteristics (firm age and whether it is listed on a national or international market), a set of two-digit industry, country and year dummies in which interviews were conducted $(2008,2009,2010) ; u_{1 i c}, u_{2 i c}$ - error terms.

According to the design, model (1) is nested in model (2). I also provide formal tests which compare different model specifications. It is important to note that the analysis can reveal only conditional correlations, but not a causal relationship. The effects in the model (1) are estimated with a two-part model. It combines the effects on $R \& D$ propensity and intensity using different underlying processes: logit for propensity equation, and a generalized linear model (GLM) with logarithm of the dependent variable for values greater than zero (intensity). Model (2) is estimated with a logistic regression.

I use two model specifications:

- I include only an aggregate measure of the management quality to test whether this variable is associated with different measures of innovation input and output. 
Review of Economic Analysis 11 (2019) 83-116

- I include quality measures for four individual management practices (operations, monitoring, targeting, incentives) to test their association with innovation measures.

I use a dummy variable for the EU (EU) to separate the fixed effects of EU countries versus CIS countries (non-EU) on innovation input and output variables.

\section{Results}

In this section, I present the findings of how management quality is correlated with innovation for two basic specifications: aggregate management quality and quality of individual management practices. Table 3 presents raw effects for $R \& D$ propensity $(1.1,2.1)$, R\&D intensity $(1.2,2.2)$, combined in a two-part model with $R \& D$ spending as a dependent variable, and the introduction of new products $(3,4)^{5}$.

I find that $R \& D$ propensity strongly increases with the aggregate measure of management quality (see column 1.1, Table 3), although the effect of R\&D intensity is relatively small and not statistically significant (see column 1.2, Table 3). For example, if the management z-score grows from the 25 th percentile to the median value, $R \& D$ probability increases by 3.2 percentage points (see Table 4, A). At the same time, the combined expected value of R\&D spending increases by 2.3 percentage points (Table $4, \mathrm{~B}$ ). The change from the 25 th to 50 th percentile is equivalent to an increase in z-score from -0.67 to 0.12 . If we keep in mind that the normalized z-scores of aggregate management quality range from roughly -4.01 to 1.84 for all firms in the data sample, the association between management quality and R\&D measures is quite strong.

It is worth noting that EU countries have on average a higher level of both R\&D propensity and intensity. Figure 4 (left chart) demonstrates the changes in the predicted probability of R\&D with different levels of management quality for EU and non-EU countries ${ }^{6}$.

\footnotetext{
${ }^{5}$ After an initial evaluation of the statistical significance for fixed assets per employee and ROTA, I find that these variables are insignificant in innovation propensity and intensity equations, which is in line with the findings of Kremp and Mairesse (2004). As in their case, coefficients are similar when I both include and exclude these variables. At the same time, the effects of management are less significant and lower. In the final estimation, I exclude fixed assets per employee and ROTA variables, which have sizable shares of missing values. The estimates with fixed assets per employee and ROTA variables are available from the author upon request.

${ }^{6} \mathrm{I}$ also try specifications with an interaction term between region and management quality to determine whether the change in management quality is associated with different R\&D probability for the two regions. As the results indicate that this term is not statistically significant in any specification, I do not include it in the final model.
} 
SIDORKIN Management Quality and Innovation in Emerging Countries

Table 3. Regression: R\&D propensity, R\&D intensity, New products introduced.

\begin{tabular}{|c|c|c|c|c|c|c|}
\hline & \multicolumn{2}{|c|}{ TPM (R\&D) } & \multicolumn{2}{|c|}{ TPM (R\&D) } & \multicolumn{2}{|c|}{ Logit (New product) } \\
\hline & Propensity & Intensity & Propensity & Intensity & Propensity & Propensity \\
\hline Models & $(1.1)$ & $(1.2)$ & $(2.1)$ & $(2.2)$ & (3) & (4) \\
\hline $\begin{array}{l}\text { Management } \\
\text { z-score }\end{array}$ & $\begin{array}{l}0.241 * * \\
(0.098)\end{array}$ & $\begin{array}{c}0.075 \\
(0.058)\end{array}$ & & & $\begin{array}{l}0.159^{*} \\
(0.093)\end{array}$ & \\
\hline $\begin{array}{l}\text { Operations } \\
\text { z-score }\end{array}$ & & & $\begin{array}{l}-0.032 \\
(0.111)\end{array}$ & $\begin{array}{l}-0.001 \\
(0.076)\end{array}$ & & $\begin{array}{l}-0.020 \\
(0.102)\end{array}$ \\
\hline $\begin{array}{l}\text { Incentives } \\
\text { z-score }\end{array}$ & & & $\begin{array}{c}0.373^{* *} \\
(0.158)\end{array}$ & $\begin{array}{l}-0.059 \\
(0.089)\end{array}$ & & $\begin{array}{c}0.125 \\
(0.144)\end{array}$ \\
\hline $\begin{array}{l}\text { Targeting } \\
\text { Z-score }\end{array}$ & & & $\begin{array}{c}-0.020 \\
(0.098) \\
\end{array}$ & $\begin{array}{l}0.122 * * \\
(0.061)\end{array}$ & & $\begin{array}{c}0.019 \\
(0.100) \\
\end{array}$ \\
\hline $\begin{array}{l}\text { Monitoring } \\
\text { z-score }\end{array}$ & & & $\begin{array}{c}0.454 * * * \\
(0.173)\end{array}$ & $\begin{array}{c}0.036 \\
(0.113)\end{array}$ & & $\begin{array}{l}0.303 * * \\
(0.143)\end{array}$ \\
\hline $\begin{array}{l}\text { European } \\
\text { Union }\end{array}$ & $\begin{array}{l}0.919 * * \\
(0.442)\end{array}$ & $\begin{array}{c}0.363 \\
(0.258) \\
\end{array}$ & $\begin{array}{c}0.949 * * \\
(0.448)\end{array}$ & $\begin{array}{c}0.289 \\
(0.256)\end{array}$ & $\begin{array}{c}0.273 \\
(0.401)\end{array}$ & $\begin{array}{c}0.272 \\
(0.403)\end{array}$ \\
\hline Ln(employees) & $\begin{array}{c}0.266^{* * *} \\
(0.129)\end{array}$ & $\begin{array}{l}-0.082 \\
(0.057)\end{array}$ & $\begin{array}{c}0.288^{* *} \\
(0.132)\end{array}$ & $\begin{array}{l}-0.091^{*} \\
(0.055)\end{array}$ & $\begin{array}{c}0.295^{* * *} \\
(0.124)\end{array}$ & $\begin{array}{c}0.302 * * \\
(0.125)\end{array}$ \\
\hline $\begin{array}{l}\text { Imports } \\
\text { pressure }\end{array}$ & $\begin{array}{c}0.711 * * * \\
(0.219)\end{array}$ & $\begin{array}{c}0.147 \\
(0.125)\end{array}$ & $\begin{array}{c}0.663 * * * \\
(0.220)\end{array}$ & $\begin{array}{c}0.171 \\
(0.131)\end{array}$ & $\begin{array}{c}0.626^{* * *} \\
(0.187)\end{array}$ & $\begin{array}{c}0.608 * * * \\
(0.187)\end{array}$ \\
\hline $\begin{array}{l}\mathrm{Ln}(\mathrm{R} \& \mathrm{D} \\
\text { spending) }\end{array}$ & & & & & $\begin{array}{l}6.170^{*} \\
(3.284) \\
\end{array}$ & $\begin{array}{l}5.992 * \\
(3.253) \\
\end{array}$ \\
\hline Other controls & $\mathrm{Yc}$ & & $\mathrm{Yc}$ & & Yes & Yes \\
\hline Country FE & $\mathrm{Yc}$ & & $\mathrm{Yc}$ & & Yes & Yes \\
\hline Industry FE & $\mathrm{Yc}$ & & $\mathrm{YG}$ & & Yes & Yes \\
\hline Pseudo $\mathrm{R}^{2}$ & 0.1 & & 0.1 & & 0.150 & 0.154 \\
\hline Prob $>\chi^{2}$ & 0.0 & & 0.0 & & 0.001 & 0.001 \\
\hline Observations & 69 & & 69 & & 697 & 697 \\
\hline
\end{tabular}

Source: Author's calculations based on the EBRD and World Bank MOI survey. Two-part model (TPM) estimates. Robust standard errors in parentheses. $*<0.10, * *<0.05, * * *<0.001$

Among individual practices (Table 3, column 2.1), the quality of incentives and monitoring have a strong positive association with R\&D propensity, as expected. In the MOI survey, incentives management has a wide definition and can be applied to business processes in general. Kremp and Mairesse (2004), for example, use a different set of questions to define knowledge management practices. One of these practices (incentive policy to retain employees), can be, in a wide sense, considered incentives management. The authors find that incentives have significant positive effects on both innovation propensity and intensity.

The quality of operations and targeting practices (Table 3, column 2.1) is not correlated with R\&D propensity. In the MOI dataset, operations and targeting have the least variation 
among all management practices, as each of them has only one underlying question, and, as a result, they depend heavily on exact wording.

As discussed above, I expect that firms which effectively work on solutions to production problems are more likely to become innovators. The operations question in the MOI survey focuses on the general handling of a wide range of problems in production processes (i.e. machinery breakdown, human error, etc.).

Although responses to this question could provide a good approximation of how firms solve operational problems, in fact $97.0 \%$ of answers (676 of 697) concentrate in two responses with the highest quality out of four. In both cases, firms solve the problem and take measures to ensure that it does not happen again (see Table B.1 in Appendix B). The difference in answers for these two scores comes from the availability of "...a continuous improvement process to anticipate problems". The actual variation in answers might not be sufficient to reveal the quality of operation practices and their association with innovation. It is likely that the incentive component plays an important role, as the complexity of the innovation process requires a different set of incentives than in production.

Targeting practices is the only group of practices that matters for $R \& D$ intensity (Table 3 , column 2.2). Although the survey question relates to the "production targets for its main product", it could be a good approximation of a corporate goal-setting strategy. Further studies are necessary to confirm whether this result persists.

A formal Likelihood Ratio specification test of models 1.1-1.2 and 2.1-2.1 suggests that I can reject the hypothesis that both constrained and unconstrained models provide similar results at a 5\% significance level, and thus, model (2.1-2.2) is preferred (see Table 5).

The combined expected value of R\&D spending for different values of management quality is depicted in Figure 3 (middle chart). The overall result is consistent with a recent study by Bloom et al. (2014a) based on a survey of about 30,000 US plants, in which the authors suggest that establishments with higher management scores show significantly higher innovation activity measured by R\&D spending per employee.

In the next step, I consider whether management quality is associated with better innovation output: whether firms develop and introduce new products to the market (a binary variable). I estimate logit regressions and present the results in Table 3, columns 3 and 4 . The effect of the aggregate management quality (column 3) is statistically insignificant at a $5 \%$ level. When examining Figure 4 (right chart), which depicts the predictive margin of innovation output for different values of management quality, it suggests that although management quality is positively associated with the probability of new product introduction, increasing management quality is marginal and there is no difference between the EU and non-EU countries. 
SIDORKIN Management Quality and Innovation in Emerging Countries

Figure 4. Predicted values of $R \& D$ propensity and $R \& D$ intensity for different management z-scores
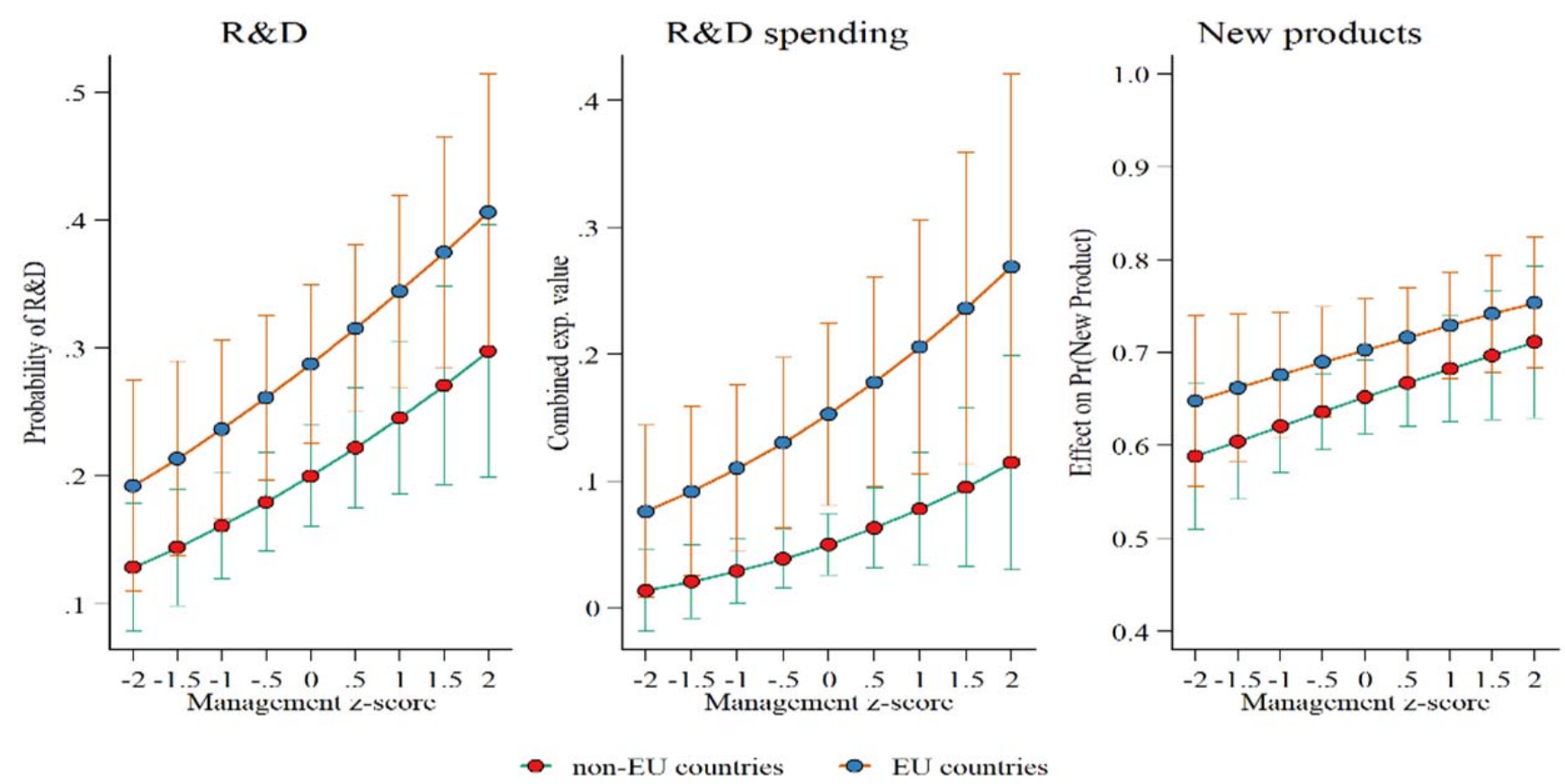

Source: Author's calculations based on the EBRD and World Bank MOI survey. EU countries include Bulgaria, Lithuania, Poland, Romania, Serbia; non-EU countries include Belarus, Kazakhstan, Russia, Ukraine, Uzbekistan.

When examining individual management practices (Table 3, model 4), I find that only monitoring management quality has a statistically significant effect (at a 5\% significance level), while the coefficients of other management practices are not significant.

A Likelihood Ratio specification test (see Table 4, C) cannot reject the hypothesis that model (4) is nested in model (3). Therefore, adding the quality of individual management practices as predictor variables does not lead to an improvement in model 3. I find that in all specifications, R\&D spending and market pressure from imports play a sizable positive role, and the coefficient is statistically significant at the $10 \%$ and $5 \%$ levels, respectively. This result confirms earlier findings of the importance of R\&D and perceived market competition for innovation output (Kremp and Mairesse, 2004; Mohnen, Mairesse, and Dagenais, 2002; Mohnen, Mairesse, and Dagenais, 2006), but does not reveal a sizable association with the quality of management. 
Table 4. Pairwise comparison of beta coefficients at the 25th and 50th percentile of management quality

\begin{tabular}{|l||c|c|c|}
\hline & beta & st. error & z-stat. \\
\hline \hline A. Model (1.1) R\&D propensity & & & \\
\hline 1. Management z-score (25 ${ }^{\text {th }}$ pctile) & $0.197^{* * *}$ & 0.019 & 10.23 \\
\hline 2. Management z-score (50 ${ }^{\text {th }}$ pctile) & $0.229^{* * *}$ & 0.018 & 12.82 \\
\hline Pairwise comparison of 1. and 2. & $0.032^{* * *}$ & 0.013 & 2.54 \\
\hline B. Model (1.1-1.2 combined) R\&D spending & & & \\
\hline 1. Management z-score (25th pctile) & $0.057^{* * *}$ & 0.013 & 4.30 \\
\hline 2. Management z-score (50th pctile) & $0.080^{* * *}$ & 0.014 & 5.64 \\
\hline Pairwise comparison of 1. and 2. & $0.023^{* *}$ & 0.011 & 2.18 \\
\hline C. Model (3). New products introduction & & & \\
\hline 1. Management z-score (25th pctile) & $0.728^{* * *}$ & 0.057 & 12.87 \\
\hline 2. Management z-score (50th pctile) & $0.759^{* * *}$ & 0.051 & 14.94 \\
\hline Pairwise comparison of 1. and 2. & 0.031 & 0.020 & 1.53 \\
\hline
\end{tabular}

Source: Author's calculations based on the EBRD and World Bank MOI survey. Robust standard errors in parentheses. $*<0.10, * *<0.05, * * *<0.001$

Table 5. Specification tests for exclusion of four individual management practices

\begin{tabular}{|l|c|c|c|}
\hline & $\mathrm{N}$ & LR test & BIC \\
\hline \hline Model (1.1-1.2) R\&D (constrained) & 697 & & 1485.60 \\
\hline Model (2.1-2.2) R\&D (unconstrained) & 697 & $14.85^{* *}$ & 1512.03 \\
\hline Model (3) R\&D (constrained) & 697 & & 965.42 \\
\hline Model (4) R\&D (unconstrained) & 697 & 3.67 & 981.39 \\
\hline
\end{tabular}

Source: Author's calculations based on the EBRD and World Bank MOI survey. Robust standard errors in parentheses. $*<0.10,{ }^{* *}<0.05, * * *<$ 0.001 
SIDORKIN Management Quality and Innovation in Emerging Countries

\subsection{Industry z-score normalization}

It is possible to argue that the measures of management quality might differ across manufacturing sectors, e.g. the management quality achieved by top firms in certain sectors might be considered mediocre in others. The differences in management z-scores by industries, on average, are not substantial at maximum values (i.e. 'best' management quality) but are striking in terms of minimum values (i.e. 'worst' management quality). Some sectors, such as electronics, have relatively higher values. I account for these differences and normalize scores by firms in each sector (2-digit code) separately. Estimation results in Table 6 show that the main conclusions, described in detail in the previous section, hold both numerically and qualitatively when I take sector-specific characteristics of management quality into account. A possible advantage of accounting for industry differences is in column 7, Table 6, which studies the relationship between aggregate management quality and new product introduction.

\subsection{Quality asymmetry analysis}

In these steps, I study asymmetries in the relationship between management quality and innovation. For this purpose, we use a piecewise regression to determine whether low or high aggregate relative quality of management has a stronger association with innovation. As management quality is the main variable of interest, I use dummy variables to distinguish between below (low) and above (high) mean management quality. The results are presented in Table 7.

In cases with the overall management quality (Table 7, columns 9.1 - 9.2), a positive relationship between management quality and R\&D holds only for firms with low quality management. At the same time, for firms with high management quality, the relationship is even negative, although not statistically significant. If we look at the relationship between management quality and innovation output (Table 7, column 11), the effect of management quality is statistically insignificant. This result suggests that dividing management quality into two intervals does not provide a meaningful explanation about the association with new product development. This relationship is weak and sensitive to the model specification.

Regarding individual management practices (Table 7, columns $10.1-10.2$ ), some results are difficult to interpret. The quality of incentives is correlated with $R \& D$ propensity at a lower quality interval, while the quality of monitoring is at a higher quality interval. The quality of incentives now has a non-linear association with R\&D spending, and the quality of targeting becomes insignificant if we compare these results to Table 3. Now the model rejects any association between the management quality of individual management practices and new 
product development (Table 7, column 12). The mechanism that drives differences in these associations is not clear from the theoretical point of view and requires further research.

In general, asymmetry analysis shows that the relationship between management quality and innovation input is of high importance for firms with below average management quality, while firms with higher quality management might not enjoy innovation acceleration

Table 6. Regression: R\&D propensity, R\&D intensity, New products introduced with management quality measure normalized by industries.

\begin{tabular}{|c|c|c|c|c|c|c|}
\hline & \multicolumn{2}{|c|}{ TPM (R\&D) } & \multicolumn{2}{|c|}{ TPM (R\&D) } & \multicolumn{2}{|c|}{ Logit (New product) } \\
\hline & Propensity & Intensity & Propensity & Intensity & Propensity & Propensity \\
\hline Models & $(5.1)$ & $(5.2)$ & $(6.1)$ & $(6.2)$ & $(7)$ & $(8)$ \\
\hline $\begin{array}{l}\text { Management } \\
\text { z-score }\end{array}$ & $\begin{array}{c}0.244^{* *} \\
(0.098)\end{array}$ & $\begin{array}{c}0.067 \\
(0.059)\end{array}$ & & & $\begin{array}{l}0.163^{*} \\
(0.093)\end{array}$ & \\
\hline $\begin{array}{l}\text { Operations } \\
\text { z-score }\end{array}$ & & & $\begin{array}{l}-0.031 \\
(0.110) \\
\end{array}$ & $\begin{array}{l}-0.006 \\
(0.076) \\
\end{array}$ & & $\begin{array}{l}-0.021 \\
(0.101)\end{array}$ \\
\hline $\begin{array}{l}\text { Incentives } \\
\text { z-score }\end{array}$ & & & $\begin{array}{c}0.398 * * \\
(0.156) \\
\end{array}$ & $\begin{array}{l}-0.065 \\
(0.088) \\
\end{array}$ & & $\begin{array}{c}0.127 \\
(0.144) \\
\end{array}$ \\
\hline $\begin{array}{l}\text { Targeting } \\
\text { z-score }\end{array}$ & & & $\begin{array}{l}-0.020 \\
(0.097)\end{array}$ & $\begin{array}{l}0.121 * * \\
(0.061)\end{array}$ & & $\begin{array}{c}0.020 \\
(0.099)\end{array}$ \\
\hline $\begin{array}{l}\text { Monitoring } \\
\text { z-score }\end{array}$ & & & $\begin{array}{c}0.435^{* *} \\
(0.173)\end{array}$ & $\begin{array}{c}0.035 \\
(0.113)\end{array}$ & & $\begin{array}{l}0.307 * * \\
(0.141)\end{array}$ \\
\hline $\begin{array}{l}\text { European } \\
\text { Union }\end{array}$ & $\begin{array}{l}0.921 * * \\
(0.442)\end{array}$ & $\begin{array}{c}0.365 \\
(0.258)\end{array}$ & $\begin{array}{c}0.949^{* *} \\
(0.448)\end{array}$ & $\begin{array}{c}0.292 \\
(0.256)\end{array}$ & $\begin{array}{c}0.273 \\
(0.401)\end{array}$ & $\begin{array}{c}0.272 \\
(0.403)\end{array}$ \\
\hline $\begin{array}{l}\text { Ln } \\
\text { (employees) }\end{array}$ & $\begin{array}{c}0.266^{* *} \\
(0.129)\end{array}$ & $\begin{array}{l}-0.081 \\
(0.056)\end{array}$ & $\begin{array}{c}0.287 * * \\
(0.132)\end{array}$ & $\begin{array}{l}-0.090^{*} \\
(0.055)\end{array}$ & $\begin{array}{c}0.294^{* *} \\
(0.125)\end{array}$ & $\begin{array}{l}0.302 * * \\
(0.125)\end{array}$ \\
\hline $\begin{array}{l}\text { Imports } \\
\text { pressure }\end{array}$ & $\begin{array}{c}0.710 * * * \\
(0.219)\end{array}$ & $\begin{array}{c}0.147 \\
(0.125)\end{array}$ & $\begin{array}{c}0.663 * * * \\
(0.220)\end{array}$ & $\begin{array}{c}0.172 \\
(0.131)\end{array}$ & $\begin{array}{c}0.626 * * * \\
(0.187)\end{array}$ & $\begin{array}{c}0.607 * * * \\
(0.187)\end{array}$ \\
\hline $\begin{array}{l}\mathrm{Ln}(\mathrm{R} \& \mathrm{D} \\
\text { spending) }\end{array}$ & & & & & $\begin{array}{l}6.166^{*} \\
(3.282) \\
\end{array}$ & $\begin{array}{l}5.990^{*} \\
(3.255) \\
\end{array}$ \\
\hline $\begin{array}{l}\text { Other } \\
\text { controls }\end{array}$ & $\mathrm{Ye}$ & & $\mathrm{Ye}$ & & Yes & Yes \\
\hline Country FE & $\mathrm{Ye}$ & & $\mathrm{Ye}$ & & Yes & Yes \\
\hline Industry FE & $\mathrm{Yg}$ & & $\mathrm{Ye}$ & & Yes & Yes \\
\hline Pseudo $\mathrm{R}^{2}$ & 0.1 & & 0.1 & & 0.150 & 0.155 \\
\hline Prob $>\chi^{2}$ & 0.0 & & 0.0 & & 0.001 & 0.001 \\
\hline Observations & 69 & & 69 & & 697 & 697 \\
\hline
\end{tabular}

Source: Author's calculations based on the EBRD and World Bank MOI survey. Two-part model (TPM) estimates. Robust standard errors in parentheses. Robust standard errors in parentheses. * $<0.10, * *<0.05, * * *<0.001$ 
SIDORKIN Management Quality and Innovation in Emerging Countries

Table 7. Regression: R\&D propensity, R\&D intensity, New products introduced - quality asymmetries

\begin{tabular}{|c|c|c|c|c|c|c|}
\hline & \multicolumn{2}{|c|}{ TPM (R\&D) } & \multicolumn{2}{|c|}{ TPM (R\&D) } & \multicolumn{2}{|c|}{ Logit (New product) } \\
\hline & Propensity & Intensity & Propensity & Intensity & Propensity & Propensity \\
\hline Models & $(9.1)$ & $(9.2)$ & $(10.1)$ & $(10.2)$ & (11) & (12) \\
\hline $\begin{array}{l}\text { Management } \\
\text { z-score }<\text { mean }\end{array}$ & $\begin{array}{c}0.496^{* * * *} \\
(0.182)\end{array}$ & $\begin{array}{l}0.183 * \\
(0.109)\end{array}$ & & & $\begin{array}{c}0.158 \\
(0.155)\end{array}$ & \\
\hline $\begin{array}{l}\text { Management } \\
\text { z-score }>\text { mean }\end{array}$ & $\begin{array}{l}-0.057 \\
(0.220)\end{array}$ & $\begin{array}{l}-0.017 \\
(0.132)\end{array}$ & & & $\begin{array}{c}0.160 \\
(0.219)\end{array}$ & \\
\hline $\begin{array}{l}\text { Operations } \\
\text { z-score }<\text { mean }\end{array}$ & & & $\begin{array}{c}0.255 \\
(0.407) \\
\end{array}$ & $\begin{array}{l}-0.066 \\
(0.143) \\
\end{array}$ & & $\begin{array}{l}-0.123 \\
(0.330) \\
\end{array}$ \\
\hline $\begin{array}{l}\text { Operations } \\
\text { z-score }>\text { mean }\end{array}$ & & & $\begin{array}{l}-0.455 \\
(0.589)\end{array}$ & $\begin{array}{l}-0.061 \\
(0.275)\end{array}$ & & $\begin{array}{c}0.160 \\
(0.475) \\
\end{array}$ \\
\hline $\begin{array}{l}\text { Incentives } \\
\text { z-score }<\text { mean }\end{array}$ & & & $\begin{array}{c}0.807 * * \\
(0.328)\end{array}$ & $\begin{array}{c}0.449 * * * \\
(0.141)\end{array}$ & & $\begin{array}{c}0.289 \\
(0.227) \\
\end{array}$ \\
\hline $\begin{array}{l}\text { Incentives } \\
\text { z-score }>\text { mean }\end{array}$ & & & $\begin{array}{l}-0.285 \\
(0.288)\end{array}$ & $\begin{array}{c}- \\
0.740 * * * \\
(0.247)\end{array}$ & & $\begin{array}{l}-0.204 \\
(0.377)\end{array}$ \\
\hline $\begin{array}{l}\text { Targeting } \\
\text { z-score }<\text { mean }\end{array}$ & & & $\begin{array}{c}0.288 \\
(0.249)\end{array}$ & $\begin{array}{c}0.162 \\
(0.147) \\
\end{array}$ & & $\begin{array}{c}0.172 \\
(0.246)\end{array}$ \\
\hline $\begin{array}{l}\text { Targeting } \\
\text { z-score }>\text { mean }\end{array}$ & & & $\begin{array}{l}-0.280 \\
(0.215) \\
\end{array}$ & $\begin{array}{c}0.073 \\
(0.136) \\
\end{array}$ & & $\begin{array}{l}-0.133 \\
(0.224) \\
\end{array}$ \\
\hline $\begin{array}{l}\text { Monitoring } \\
\text { Z-score }<\text { mean }\end{array}$ & & & $\begin{array}{c}0.304 \\
(0.230) \\
\end{array}$ & $\begin{array}{l}-0.037 \\
(0.158)\end{array}$ & & $\begin{array}{c}0.312 \\
(0.193) \\
\end{array}$ \\
\hline $\begin{array}{l}\text { Monitoring } \\
\text { z-score }>\text { mean }\end{array}$ & & & $\begin{array}{l}0.660^{*} \\
(0.371)\end{array}$ & $\begin{array}{c}0.141 \\
(0.262)\end{array}$ & & $\begin{array}{c}0.214 \\
(0.362) \\
\end{array}$ \\
\hline European Union & $\begin{array}{l}0.929 * * \\
(0.439)\end{array}$ & $\begin{array}{c}0.380 \\
(0.255)\end{array}$ & $\begin{array}{l}0.961 * * \\
(0.449)\end{array}$ & $\begin{array}{c}0.309 \\
(0.251)\end{array}$ & $\begin{array}{c}0.273 \\
(0.402)\end{array}$ & $\begin{array}{c}0.277 \\
(0.404)\end{array}$ \\
\hline Ln(employees) & $\begin{array}{c}0.269 * * \\
(0.129) \\
\end{array}$ & $\begin{array}{l}-0.081 \\
(0.057)\end{array}$ & $\begin{array}{c}0.292 * * \\
(0.132) \\
\end{array}$ & $\begin{array}{c}-0.087 \\
(0.056) \\
\end{array}$ & $\begin{array}{c}0.295 * * \\
(0.125) \\
\end{array}$ & $\begin{array}{c}0.297 * * \\
(0.126) \\
\end{array}$ \\
\hline Imports pressure & $\begin{array}{c}0.704 * * * \\
(0.219) \\
\end{array}$ & $\begin{array}{c}0.159 \\
(0.154) \\
\end{array}$ & $\begin{array}{c}0.661 * * * \\
(0.226)\end{array}$ & $\begin{array}{c}0.160 \\
(0.139) \\
\end{array}$ & $\begin{array}{c}0.626^{* * *} * \\
(0.186)\end{array}$ & $\begin{array}{c}0.598 * * * \\
(0.189)\end{array}$ \\
\hline Ln(R\&D spending) & & & & & $\begin{array}{l}6.170 * \\
(3.289)\end{array}$ & $\begin{array}{l}5.902^{*} \\
(3.200)\end{array}$ \\
\hline Other controls & \multicolumn{2}{|c|}{ Yes } & \multicolumn{2}{|c|}{ Yes } & Yes & Yes \\
\hline Country FE & \multicolumn{2}{|c|}{ Yes } & \multicolumn{2}{|c|}{ Yes } & Yes & Yes \\
\hline Industry FE & \multicolumn{2}{|c|}{ Yes } & \multicolumn{2}{|c|}{ Yes } & Yes & Yes \\
\hline Pseudo $\mathrm{R}^{2}$ & \multicolumn{2}{|c|}{0.116} & \multicolumn{2}{|c|}{0.133} & 0.150 & 0.156 \\
\hline Prob $>\chi^{2}$ & \multicolumn{2}{|c|}{0.001} & \multicolumn{2}{|c|}{0.001} & 0.001 & 0.001 \\
\hline Observations & \multicolumn{2}{|c|}{697} & \multicolumn{2}{|c|}{697} & 697 & 697 \\
\hline
\end{tabular}

Source: Author's calculations based on the EBRD and World Bank MOI survey. Two-part model (TPM) estimates. Robust standard errors in parentheses. $*<0.10, * *<0.05, * * *<0.001$ 
associated with better management practices. From the regional perspective, this finding might also contribute to understanding why knowledge production is highly variable and not very efficient in comparison with the production of outputs, as found, for example, by Drivas at al. (2018) for US states. For firms that are close to the technological frontier, dynamic capabilities are necessary, but not sufficient factors for innovation success. Other external factors, such as imports pressure from competitors (Table 7, columns $11-12$ ), become more important for new product development at this stage.

\section{Conclusion}

This paper explicitly focuses on the association between the quality of aggregate management, individual management practices, and innovation (input and output) in emerging countries. The empirical analysis presented in the paper helps to explain whether management quality is associated with firms' $R \& D$ propensity, $R \& D$ intensity, and the introduction of new products. This study provides evidence that better aggregate management quality is correlated with a higher propensity of firms to invest in R\&D. However, the correlation with the intensity of R\&D is not statistically significant. Finally, the association between management quality and the introduction of new products is positive, but this relationship is weak. The improvement of management quality is not directly related to a significant increase in the probability of new product development. The results hold after controlling for differences in management quality by industries. Although management quality does not guarantee the successful introduction of new products, it may have an indirect positive result through higher R\&D propensity and intensity.

These findings may have important policy implications because they highlight the possible benefits and limitations of management as a dynamic capability to stimulate innovation activities and improve the competitiveness of firms. Public interventions, such as management training for small business owners or sharing best practices, may be effective tools to accelerate the development of firms' dynamic capabilities, particularly for firms that lag behind in terms of management quality.

Although I expected that the quality of all management practices would play an important role for new product introduction in emerging countries, I did not find support for this hypothesis in the empirical results, as the effects were heterogeneous and often non-linear. This calls for further empirical research to explain the mechanism behind this heterogeneity and establish a causal relationship between the improvement of management quality and innovation. Can this result be confirmed if an alternative (stricter) definition of management quality practices is applied? Does the business environment intensify or weaken the positive effects of management quality? Can the effects of management quality on innovation output be indirect - through the innovation input? This result would be consistent with the findings of Cantner and Joel (2007), in which the direct effects of knowledge management on 
SIDORKIN Management Quality and Innovation in Emerging Countries

innovation success are not significant, while the indirect impact through innovation input and cooperation is sizable.

Instead of technological innovations, firms could make innovations in the management and organization practices directly. For example, in the case of small firms, innovation in management can serve as a substitute for investments in R\&D (Rammer, Czarnitzki, and Spielkamp, 2009). In this case, the development of capabilities would serve as an important innovation process. Further observational studies and randomized controlled trials (RCT) analyzing quality management practices using wider definitions of management quality, rich panel data, and effects heterogeneity are needed, as these would help to establish the direct and indirect causal links between management practices and the innovation output of different firms.

\section{References}

Adams R., Bessant J., and Phelps R. (2006), Innovation management measurement: A review, International Journal of Management Reviews 8(1), 21-47. https://doi.org/10.1111/j.14682370.2006.00119.x

Atkin, D., Chaudhry, A., Chaudry, S., Khandelwal, A.K., Verhoogen, E. (2017), Organizational barriers to technology adoption: The evidence from soccer-ball producers in Pakistan, Quarterly Journal of Economics 132(3): 1101-1164. https://doi.org/10.1093/qje/qjx010

Audretsch, D. B., Feldman, M. P. (1996), R\&D Spillovers and the Geography of Innovation and Production. American Economic Review 86 (3), 630 - 640. |https://www.jstor.org/stable/2118216

Bender, S., Bloom, N., Card, D., Van Reenen, J., Wolter, S. (2018), Management practices, workforce selection, and productivity. Journal of Labor Economics 38(S1), S371-S409. https://doi.org/10.1086/694107

Birkinshaw, J., Hamel, G., and Mol, M. J. (2008), Management Innovation. Academy of Management Review 33 (4), 825-845. https://doi.org/10.5465/amr.2008.34421969

Birkinshaw, J., Mol, M. J. (2009), The sources of management innovation: When firms introduce new management practices, Journal of Business Research 62(12), 1269-1280. https://doi.org/10.1016/j.jbusres.2009.01.001

Bloom, N., Schweiger, H., and Reenen, J. V. (2012), The land that lean manufacturing forgot? Economics of Transition 20(4), 593-635. https://doi.org/10.1111/j.14680351.2012.00444.x

Bloom, N., Lemos, R., Sadun, R., Scur, D., and Van Reenen, J. (2014), The new empirical economics of management. Journal of the European Economic Association 12(4), 835876. https://doi.org/10.1111/jeea.12094 
Bloom, N., Brynjolfsson, E., Foster, L., Jarmin, R.S., Patnaik, M., Saporta-Eksten, I., Van Reenen, J. (2017), What Drives Differences in Management? NBER Working Paper 23300, https://doi.org/10.3386/w23300

Broszeit, S., Fritsch, U., Görg, H., Laible, M.-C. (2016), Management practices and productivity in Germany, IZA Discussion Paper Series No. 10370. Available at https://ssrn.com/abstract=2872627

Cantner, U., Joel, K. (2007), Functional Chains of Knowledge Management - Effects on Firms' Innovative Performance. European Journal of Economic and Social Systems 20(2): 211-230. https://doi.org/10.3166/ejess.20.211-230

Cirera, X., Maloney, W.F. (2017), The Innovation Paradox, International Bank for Reconstruction and Development / The World Bank. https://openknowledge.worldbank.org/handle/10986/28341

Clark, K. B, Fujimoto, T. (1989), Lead Time in Automobile Product Development Explaining the Japanese Advantage. Journal of Engineering and Technology Management 6 (1) 25 58. https://doi.org/10.1016/0923-4748(89)90013-1

Crépon, B., Duguet, E., Mairesse, J. (1998), Research, Innovation And Productivity: An Econometric Analysis At The Firm Level. Economics of Innovation and New Technology 7 (2), 115-158. https://doi.org/10.1080/10438599800000031

Dakhli, M., and De Clercq, D. 2004. Human Capital, Social Capital, and Innovation: a Multicountry Study. Entrepreneurship \& Regional Development 16 (2), 107-128. https://doi.org/10.1080/08985620410001677835

Drivas, K., Economidou, C., Tsionas, E.G. (2018), Production of Output and Ideas: Efficiency and Growth Patterns in the United States, Regional Studies, 52(1), 105-118. https://doi.org/10.1080/00343404.2016.1275536

Drivas, K., Lei, Z., Wright, B.D. (2017), Academic Patent Licenses: Roadblocks or signposts for nonlicensee cumulative innovation? Journal of Economic Behavior \& Organization 137, 282 - 303. https://doi.org/10.1016/j.jebo.2017.03.018

Earl, L., Gault, F. (2004), Knowledge Management: Size Matters. In Measuring Knowledge Management in the Business Sector: First Steps, OECD Publishing, Paris. https://doi.org/10.1787/9789264100282-en

Elche-Hotelano, D. (2011), Sources of Knowledge, Investments and Appropriability as Determinants of Innovation: An Empirical Study in Service Firms. Innovation 13 (2): 220 - 235. https://doi.org/10.5172/impp.2011.13.2.220

Griffin, A. and Hauser, J. R. (1996), Integrating R\&D and marketing: A review and analysis of the literature. Journal of Production Innovation Management 13(3), 191-215. https://doi.org/10.1111/1540-5885.1330191

Guadalupe, M., Kuzmina, O., Thomas, C. (2012), Innovation and Foreign Ownership. American Economic Review 102 (7): 3594 - 3627. https://doi.org/10.1257/aer.102.7.3594 
SIDORKIN Management Quality and Innovation in Emerging Countries

Hamel, G. (2006), The Why, What, and How of Management Innovation. Harward Business Review 84 (2), 72-84.

Hayes, R., Weelwright, S., and Clark, K. (1988), Dynamic manufacturing creating the learning organization. The Free Press: New York.

Hellmann, T, Thiele, V. (2011), Incentives and innovation: A multitasking approach, American Economic Journal: Microeconomics, 3: 78 - 128. https://doi.org/10.1257/mic.3.1.78

Helper, S., Henderson, R. (2014), Management Practices, Relational Contracts, and the Decline of General Motors. Journal of Economic Perspectives 28(1), 49-72. https://doi.org/10.1257/jep.28.1.49

Huergo, E., Jaumandreu, J. (2004), How Does Probability of Innovation Change with Firm Age? Small Business Economics $22 \quad$ (3-4), 193-207, https://doi.org/10.1023/B:SBEJ.0000022220.07366.b5

Jaffe, A.B. (1989), Real Effects of Academic Research. American Economic Review 79(5), 957-970. https://www.jstor.org/stable/1831431

Kim, L. (1997), Imitation to Innovation: The Dynamics of Korea's Technological Learning. Harvard Business Press.

Kim, D.-Y., Kumar, V., Kumar, U. (2012), Relationship Between Quality Management Practices and Innovation. Journal of Operations Management 30 (4), 295-315. https://doi.org/10.1016/j.jom.2012.02.003

Kremp, E. Mairesse, J. (2004), Knowledge management, innovation, and productivity: a firm level exploration based on French manufacturing CIS3 data. NBER Working Paper 10237. https://doi.org/ 10.3386/w10237

Laursen, K., Foss, N.J. (2003), New Human Resource Management Practices, Complementarities and the Impact on Innovation Performance. Cambridge Journal of Economics 27 (2), 243-263. https://doi.org/10.1093/cje/27.2.243

Lerner, J., Wulf, J. (2007), Innovation and Incentives: Evidence from Corporate R\&D. Review of Economics and Statistics 89 (4), 634-644. https://doi.org/10.1162/rest.89.4.634

Mairesse, J. and Mohnen, P. (2010), Using innovations surveys for econometric analysis. NBER Working Paper 15857, https://doi.org/10.3386/w10237

Makri, M., Lane, P. J. Gomez-Mejia, L. R. (2006), CEO Incentives, Innovation, and Performance in Technology-Intensive Firms: A Reconciliation of Outcome and BehaviorBased Incentive Schemes. Strategic Management Journal 27 (11), 10571080. https://doi.org/10.1002/smj.560

Mohnen, P., Hall, B.H. (2014), Innovation and Productivity: An Update. Eurasian Business Review 3 (1), 47 - 65. https://doi.org/10.14208/BF03353817 
Mohnen, P., Mairesse, J., Dagenais, M. (2006), Innovativity: A Comparison Across Seven European Countries. Economics of Innovation and New Technology 15 (4-5), 391-413. https://doi.org/10.1080/10438590500512950

Mohnen, P., Dagenais, M. (2002), Towards an Innovation Intensity Index. The Case of CIS-I in Denmark and Ireland. In Kleinknecht A., Mohnen P. (eds) Innovation and Firm Performance. Econometric Explorations of Survey Data. Palgrave Macmillan, London. https://doi.org/10.1057/9780230595880_1

Montoya-Weiss, M. M., Calantone, R. (1994), Determinants of New Product Performance: A Review and Meta-Analysis. Journal of Product Innovation Management 11 (5), 397-417. https://doi.org/10.1111/1540-5885.1150397

Rammer, C., Czarnitzki, D., Spielkamp, A. (2009), Innovation Success of Non-R\&DPerformers: Substituting Technology by Management in SMEs. Small Business Economics 33 (1), 35-58. https://doi.org/10.1007/s11187-009-9185-7

Schweiger, H., Friebel, G. (2013), Management Quality, Ownership, Firm Performance and Market Pressure in Russia. Open Economies Review 24 (4), 763-788. https://doi.org/10.1007/s11079-013-9270-z

Soskice, D. (1997), German Technology Policy, Innovation, and National Institutional Frameworks. Industry and Innovation 4 (1), 75-96. https://doi.org/10.1080/13662719700000005

Teece, D. (1986), Profiting from technological innovation: Implications for integration, collaboration, licensing and public policy. Research Policy 15(6), 285-305. https://doi.org/10.1016/0048-7333(86)90027-2

Teece, D. and Pisano, G. (1994), The dynamic capabilities of firms: an introduction. Industrial and corporate change 3(3), 537-556. https://doi.org/10.1093/icc/3.3.537-a

Trott, P. (2012), Innovation management and new product development. 5th edn., Financial Times/Prentice Hall, Harlow, England; New York.

Van der Panne, G., Van Beers, C., Kleinknecht, A. (2003), Success and Failure of Innovation: A Literature Review. International Journal of Innovation Management 7(3), 309-338. https://doi.org/10.1142/S1363919603000830

Walker, R. M., Damanpour, F., Devece, C.A. (2011), Management Innovation and Organizational Performance: The Mediating Effect of Performance Management. Journal of Public Administration Research and Theory 21(2), 367-386. https://doi.org/10.1093/jopart/muq043. 
SIDORKIN Management Quality and Innovation in Emerging Countries

\section{Appendix}

\section{Appendix A-Summary statistics}

Table A.1: Summary statistics: Time periods

\begin{tabular}{|l||c|c|}
\hline Variables & Obs. & Frequency \\
\hline \hline 2008 & 393 & 56.385 \\
\hline $2009-2010$ & 304 & 43.615 \\
\hline Total & 697 & 100.00 \\
\hline
\end{tabular}

Table A.2: Summary statistics: Industries

\begin{tabular}{|l||c|c|}
\hline Variables & Obs. & Frequency \\
\hline \hline Other manufacturing & 199 & 28.551 \\
\hline Food & 153 & 21.951 \\
\hline Textiles & 26 & 3.730 \\
\hline Garments & 42 & 6.026 \\
\hline Chemicals & 23 & 3.300 \\
\hline Plastics and rubber & 30 & 4.304 \\
\hline Non-metallic mineral products & 52 & 7.461 \\
\hline Basic metals & 5 & 0.717 \\
\hline Fabricate metal products & 89 & 12.769 \\
\hline Machinery and equipment & 53 & 7.604 \\
\hline Electronics & 25 & 3.587 \\
\hline Total & 697 & 100.00 \\
\hline
\end{tabular}




\section{Appendix B- Management practices - core questions}

Table B.1: Management practices - core questions. Operations R.1. What normally happens when a process problem arises, for example, machinery break-down human errors or failures in communication?

\begin{tabular}{lcc}
\hline \hline & $\begin{array}{c}\text { Score in } \\
\text { questionnaire }\end{array}$ & $\begin{array}{c}\text { Management } \\
\text { score }\end{array}$ \\
& 1 & 1 \\
$\begin{array}{l}\text { Nothing is done about it. } \\
\text { We fix it but do not take further }\end{array}$ & 2 & 2 \\
measures. & 3 & 3 \\
$\begin{array}{l}\text { We fix it and we take measures to } \\
\text { make sure that it does not happen }\end{array}$ & & \\
$\begin{array}{l}\text { again. } \\
\text { We fix it and we take measures to }\end{array}$ & 4 & 4 \\
make sure that it does not happen \\
$\begin{array}{l}\text { again and we also have a continuous } \\
\text { improvement process to anticipate } \\
\text { problems. }\end{array}$ & & \\
$\begin{array}{l}\text { Don't know } \\
\text { Refusal }\end{array}$ & -9 & \\
\hline \hline
\end{tabular}

Table B.2: Management practices - core questions. Targets R.4. What is the timescale of this establishment's production targets for the main product?

\begin{tabular}{lcc}
\hline \hline & $\begin{array}{l}\text { Score in } \\
\text { questionnaire }\end{array}$ & $\begin{array}{c}\text { Management } \\
\text { score }\end{array}$ \\
$\begin{array}{l}\text { The main focus is on short-term (less than } \\
\text { one year) production targets for the main } \\
\text { product. }\end{array}$ & 1 & 2 \\
$\begin{array}{l}\text { There are short- and long-term (more than } \\
\text { three years) production targets for the main } \\
\text { product, but they are set independently. }\end{array}$ & 2 & 3 \\
$\begin{array}{l}\text { There are integrated short- and long-term } \\
\text { production targets for the main product. }\end{array}$ & 3 & 4 \\
$\begin{array}{l}\text { There are no production targets set for the } \\
\text { main product. }\end{array}$ & 4 & 1 \\
$\begin{array}{l}\text { Don't know } \\
\text { Refusal }\end{array}$ & -9 & 1 \\
\hline \hline
\end{tabular}


SIDORKIN Management Quality and Innovation in Emerging Countries

Table B.3: Management practices - core questions. Incentives R.7. How do you reward this establishment's production target achievement?

\begin{tabular}{lcc}
\hline \hline & \multicolumn{2}{c}{ Score in } \\
& questionnaire & score \\
There are no rewards. & 1 & 1 \\
$\begin{array}{l}\text { Only top and middle } \\
\text { management is rewarded. }\end{array}$ & 2 & 2 \\
All staff is rewarded. & 3 & 3 \\
Don't know & -9 &. \\
Refusal & -8 &. \\
\hline \hline
\end{tabular}

Table B.4. Management practices - core questions. Incentives O.14. Which of the following best corresponds to the main way employees are promoted in this establishment??

\begin{tabular}{lcc}
\hline \hline & $\begin{array}{c}\text { Score in } \\
\text { questionnaire }\end{array}$ & $\begin{array}{c}\text { Management } \\
\text { score }\end{array}$ \\
$\begin{array}{l}\text { Promotions are based solely on } \\
\text { individual's effort and ability. }\end{array}$ & 1 & 3 \\
$\begin{array}{l}\text { Promotions are based partly on } \\
\text { individual's efforts and ability, and }\end{array}$ & & \\
partly on other factors such as tenure & 2 & 2 \\
(how long they have worked at the & & \\
firm. & & \\
$\begin{array}{l}\text { Promotions are based mainly on factors } \\
\text { other than on individual's efort and }\end{array}$ & 3 & 1 \\
ability, such as tenure. & 4 & $\cdot$ \\
Other. & -7 & $\cdot$ \\
Does not apply & -9 & $\cdot$ \\
Don't know &
\end{tabular}


Table B.5. Management practices - core questions. Incentives O.15. Which of the following best corresponds to this establishment's main policy when dealing with employees who do not meet expectations in their position?

\begin{tabular}{lcc}
\hline \hline & $\begin{array}{c}\text { Score in } \\
\text { questionnaire }\end{array}$ & $\begin{array}{c}\text { Management } \\
\text { score }\end{array}$ \\
\hline $\begin{array}{l}\text { They are rarely or never moved from } \\
\text { their position. }\end{array}$ & 1 & 1 \\
$\begin{array}{l}\text { They usually stay in their positions } \\
\text { for at least a year before action is } \\
\text { taken. }\end{array}$ & 2 & 2 \\
$\begin{array}{l}\text { They are rapidly helped and re- } \\
\text { trained, and then dismissed if their }\end{array}$ & 3 & \\
performance does not improve. & & 3 \\
$\begin{array}{l}\text { Other. } \\
\text { Does not apply }\end{array}$ & 4 &. \\
Don't know & -7 & $\cdot$ \\
\hline \hline
\end{tabular}

Table B.6: Management practices - core questions. Monitoring R.2a. How many production performance indicators are monitored in this establishment?

\begin{tabular}{lcc}
\hline \hline & $\begin{array}{l}\text { Score in } \\
\text { questionnaire }\end{array}$ & $\begin{array}{c}\text { Management } \\
\text { score }\end{array}$ \\
$\begin{array}{l}\text { None. } \\
\text { One or two } \\
\text { production } \\
\text { performance } \\
\text { indicators (for } \\
\text { example, volume } \\
\text { and quality). }\end{array}$ & 1 & 1 \\
$\begin{array}{l}\text { More than two } \\
\text { production } \\
\text { performance } \\
\text { indicators. }\end{array}$ & 3 & 2 \\
$\begin{array}{l}\text { Don't know } \\
\text { Refusal }\end{array}$ & -9 & 3 \\
\hline \hline
\end{tabular}


SIDORKIN Management Quality and Innovation in Emerging Countries

Table B.7: Management practices - core questions. Monitoring R.2b. How frequently are these production performance indicators collected in this establishment?

\begin{tabular}{lcc}
\hline \hline & $\begin{array}{c}\text { Score in } \\
\text { questionnaire }\end{array}$ & $\begin{array}{c}\text { Management } \\
\text { score }\end{array}$ \\
\hline Yearly & 1 & 1 \\
Quarterly & 2 & 2 \\
Monthly & 3 & 3 \\
Weekly & 4 & 4 \\
Daily & 5 & 5 \\
Hourly & 6 & 6 \\
Don't & -9 & 1 \\
know & & 0 \\
Never & $\cdot$ & \\
\hline \hline
\end{tabular}

Table B.8. Management practices - core questions. Monitoring R.2c. How frequently are production performance indicators are shown to managers?

\begin{tabular}{lcc}
\hline \hline & Score in & Management \\
Annually & 2 & score \\
Semi-annually & 3 & 2 \\
Quarterly & 4 & 3 \\
Monthly & 5 & 4 \\
Weekly & 6 & 5 \\
Daily & 7 & 6 \\
Hourly & 8 & 7 \\
Never & 1 & 8 \\
Other & 10 & 1 \\
Don't know & -9 & depends on answer \\
\hline \hline
\end{tabular}


Table B.9. Management practices - core questions. Monitoring R.2d. How frequently are production performance indicators shown to workers?

\begin{tabular}{lcc}
\hline \hline & $\begin{array}{c}\text { Score in } \\
\text { questionnaire }\end{array}$ & $\begin{array}{c}\text { Management } \\
\text { score }\end{array}$ \\
Annually & 2 & 2 \\
Semi-annually & 3 & 3 \\
Quarterly & 4 & 4 \\
Monthly & 5 & 5 \\
Weekly & 6 & 6 \\
Daily & 7 & 7 \\
Hourly & 8 & 8 \\
Never & 1 & 1 \\
Other & 10 & depends on answer \\
Don't know & -9 & 1 \\
\hline \hline
\end{tabular}

Table B.10. Management practices - core questions. Monitoring R.3. How often are production performance indicators reviewed by top or middle managers?

\begin{tabular}{lcc}
\hline \hline & $\begin{array}{c}\text { Score in } \\
\text { questionnaire }\end{array}$ & $\begin{array}{c}\text { Management } \\
\text { score }\end{array}$ \\
\hline $\begin{array}{l}\text { They are continually } \\
\text { reviewed. }\end{array}$ & 1 & 3 \\
$\begin{array}{l}\text { They are periodically } \\
\text { reviewed. }\end{array}$ & 2 & 2 \\
They are rarely reviewed. & 3 & 1 \\
Don't know & -9 & 1 \\
Refusal & -8 & $\cdot$ \\
\hline \hline
\end{tabular}


SIDORKIN Management Quality and Innovation in Emerging Countries

Table B.11. Management practices - core questions. Monitoring R.6. Does this establishment use any production performance indicators to compare di erent teams of employees in the production line, in di erent shifts, or similar?

\begin{tabular}{lcc}
\hline \hline & Score in & Management \\
& questionnaire & score \\
Yes & 1 & 2 \\
No & 2 & 1 \\
Don't know & -9 &. \\
\hline
\end{tabular}

\section{Appendix C- MOI sampling methodology}

MOI sampling methodology uses a random sample representative of the manufacturing sector and ensures large enough sample sizes for the manufacturing sector to conduct statistically robust analyses with levels of precision at a minimum $7.5 \%$ precision for $90 \%$ confidence intervals about the differences in management practices across countries.

The Management, Organization and Innovation (MOI) survey includes (according to ISIC, revision 3.1) all manufacturing sectors (group D). The sample frame for each country should include only establishments with at least fifty (50) but less than 5000 employees. The survey was administered face-to-face, with generally the same person the factory, production or operation manager - responding to all sections.

If available and of sufficient quality in terms of representativeness of the manufacturing sector, the preferred sample frame was Bureau van Dijk's Orbis database, which contained published balance sheet and pro $t$ and loss statements. When this source is not available or is of poor quality, the official sample frames (Business Environment and Enterprise Performance Survey, see https://ebrd-beeps.com/ for details) without financial performance information can be used. The sample frame downloaded from Orbis was cleaned by the EBRD through the addition of regional variables, updating addresses and phone numbers of companies. MOI (ORBIS) sample frame was not available for Kazakhstan and Uzbekistan, so BEEPS sample frame was used there. No strati cation was used in the majority of the countries, but the sample was selected randomly, and covered all regions and at least a 25 per cent response rate was a requirement.

MOI survey also added location as another dimension to the sampling strategy, ensuring that the sample frame was stratified by region, where the laws and regulations that might have an impact on management practices vary across regions. Strati cation along industries (two- 
digit codes) within manufacturing and establishment size were not required for MOI sampling design.

Item non-response was addressed by two strategies:

- For sensitive questions that may generate negative reactions from the respondent, such as ownership information, enumerators were instructed to collect the refusal to respond as (8).

- Establishments with incomplete information were re-contacted in order to complete this information, whenever necessary. However, there were clear cases of low response.

Survey non-response was addressed by maximizing e orts to contact establishments that were initially selected for interviews. Up to 15 attempts (but at least 4 attempts) were made to contact an establishment for interview at different times/days of the week before a replacement establishment (with similar characteristics) was suggested for interview. Survey non-response did occur, but substitutions were made in order to potentially achieve the goals.

\section{Appendix D- Merging MOI and ORBIS datasets}

The merged MOI-ORBIS dataset comes from EBRD and was also used in the paper by Schweiger and Friebel (2013). The authors write "We were able to perfectly match the survey data back to the Bureau van Dijk's Orbis database on the basis of the Bureau van Dijk's firm identification number, which was included in the survey data. The latter also included the name, address and phone number of the firm, and we cross-checked the firm names and addresses manually after the matching. In some of the countries that did not use Bureau van Dijk's Orbis database as a sample frame, we were able to find some of the firms in the Orbis database on the basis of their name, industry and address at a later date when the coverage in Orbis improved" (Schweiger and Friebel 2013, p.23). 